\title{
PERBANDINGAN APLIKASI PROGRAM MICROSOFT PROJECT, PROJECT LIBRE DAN GANTT PROJECT DALAM PENJADWALAN PROYEK KONSTRUKSI
}

\author{
Nuryasin Abdillah \\ Program Studi Teknik Sipil, Sekolah Tinggi Teknologi Dumai \\ JL. Utama Karya Bukit Batrem II \\ Email : yasinabdillah10@gmail.com
}

\begin{abstract}
ABSTRAK
Untuk membuat penjadwalan suatu proyek dibutuhkan ketelitian yang tinggi untuk menghindari terjadinya kesalahan. Ketelitian yang dibutuhkan untuk membuat penjadwalan suatu proyek tidaklah sama. Oleh karna itu diperlukan aplikasi program yang dapat membantu pembuatan jadwal. Terdapat berbagai jenis aplikasi program untuk penjadwalan proyek diantaranya Microsoft Project, Project Libre, dan Gantt Project. Ketiga aplikasi program ini mempunyai kelebihan dan kekurangan nya masingmasing. Pada penelitian ini akan dibahas cara menggunakan aplikasi program untuk membuat penjadwalan proyek dan membandingkan kelebihan dan kelemahan tiga aplikasi program dengan menggunakan 12 kategori menurut J.D Witt. Hasil penelitian menunjukan kemampuan yang dimiliki oleh Project Libre sangat mirip dengan kemampuan yang dimiliki Microsoft Project. Tetapi Projecr Libre memiliki keunggulan lebih dari Microsoft Project karna merupakan aplikasi program yang open source dan tidak berbayar. Sedangkan kemampuan yang dimiliki Gantt Project masih jauh dari kemampuan yang dimiliki oleh Microsoft Project dan Project Libre. Hal ini dikarnakan Gantt Project merupakan aplikasi program khusus penjadwalan saja. Namun Gantt Project merupakan aplikasi program yang tidak berbayar dan open source sehingga source codenya dapat dilihat oleh orang lain dan membiarkan orang lain mengetahui cara kerja aplikasi program dan sekaligus memperbaiki kelemahan-kelemahan yang ada pada aplikasi program.
\end{abstract}

Kata Kunci: penjadwalan proyek, aplikasi program, Microsoft Project, Project Libre, Gantt Project.

\begin{abstract}
To make scheduling a project requires high precision to avoid errors. The precision required to make the scheduling of a project is not the same. Therefore it is necessary application program that can help the making of schedule. There are various types of program applications for project
\end{abstract}


scheduling such as Microsoft Project, Project Libre, and Gantt Project. The three applications of this program have their advantages and disadvantages respectively. In this study will be discussed how to use the application program to create project scheduling and compare the advantages and disadvantages of three application programs using 12 categories according to J.D Witt. The results show that the ability of Project Libre is very similar to the capabilities of Microsoft Project. But Projecr Libre has more advantages than Microsoft Project because it is an open source application program and not paid. While the ability of Gantt Project is still far from the capabilities owned by Microsoft Project and Project Libre. This is dikarnakan Gantt Project is a special program scheduling application only. But Gantt Project is a non-paid and open source program application so that its source code can be viewed by others and let others know how the application of the program works and simultaneously fix the weaknesses that exist in the application program.

Keywords: project scheduling, application program, Microsoft Project, Project Libre, Gantt Project. 


\section{Pendahuluan}

Pada masa sekarang ini, industri konstruksi merupakan suatu industri ekonomi nasional yang berhubungan dengan persiapan Iahan dan pembangunan, percepatan, dan perbaikan bangunan, struktur, dan properti lain. Atas dasar itu, industri konstruksi merupakan salah satu industri yang paling berkembang di seluruh dunia. Pertumbuhan industri konstruksi sejalan dengan pertumbuhan ekonomi di suatu negara (Widiasanti dan Lenggogeni, 2013) .

Penjadwalan yang baik adalah panduan untuk melaksanakan pekerjaan proyek konstruksi secara efektif dan efisien. Penggunaan aplikasi program komputer (software) merupakan solusi untuk meminimalisir kesalahan dalam proses penjadwalan. Selain itu, untuk proyek-proyek berskala besar dengan aktivitas yang banyak sangat tidak mungkin dikendalikan secara manual untuk mendapatkan hasil yang optimum.

Menurut R.J Mockler (1972), pengendalian adalah usaha yang sistematis untuk menentukan standar yang sesuai dengan sasaran dan tujuan perencanaan, merancang system informasi, membandingkan pelaksanaan dengan standar, menganalisis kemungkinan penyimpangan, kemudian melakukan tindakan koreksi yang diperlukan agar sumber daya dapat digunakan secara efektif dan efisien dalam rangka mencapai sasran dan tujuan.

Penggunaan aplikasi program menjadi salah satu solusi untuk meminimalisir kesalahan dalam penjadwalan. Microsoft Project, Project Libre, dan Gantt Project merupakan aplikasi program yang dapat digunakan untuk membuat penjadwalan pada proyek.

Adapun tujuan penelitian ini adalah untuk mengetahui cara penggunaan aplikasi program secara umum dalam penjadwalan pada proyek konstruksi dan untuk mengetahui perbandingan kelebihan dan kekurangan ketiga aplikasi program terserbut dalam penjadwalan pada proyek konstruksi.

\section{Metodologi Penelitian}

Studi literatur dilakukan dengan tujuan untuk mendapatkan gambaran mengenai teori dan konsep yang akan digunakan dalam menyelesaikan masalah yang diteliti serta untuk mendapatkan dasar-dasar referensi yang kuat dalam melaksanakan penelitian. Studi literature dilakukan dengan mengekplorasi buku-buku, jurnal, dan sumber-sumber lain terkait dengan penelitian.

Dalam proses penyelesaian suatu masalah dibutuhkan data yang sesuai dengan permasalahan yang ditangani. Data yang diperlukan dalam 
penyusunan Laporan Tugas Akhir ini didapat melalui studi kasus Supervisi Penataan Pelabuhan Dumai yang diperoleh dari konsultan pengawas yaitu PT. Diagonal Jaya Multi Kreasi. Lokasi proyek ini terletak di Jl. Pelabuhan, Dumai Kota, Kota Dumai, Riau.

Proses input data dimulai dari memasukkan item pekerjaan yang terdapat pada Proyek Supervisi Penataan Pelabuhan Dumai. Kemudian memasukkak durasi, dan membuat hierarki atau hubungan antar pekerjaan. Kemudian mengatur kalender untuk mengatur waktu kerja yang diinginkan. Lalu memasukkan jenis sumber daya dan biaya yang dibutuhkan.

Penulis akan menganalisis cara penggunakan aplikasi program untuk penjadwalan pada proyek konstruksi menggunakan data yang telah didapatkan dari studi kasus Supervisi Penataan Pelabuhan Dumai. Dalam menilai aplikasi program digunakan 12 kriteria evaluasi yang diambil dari penelitian Octavia dan Tandoyo (2013).

\section{Hasil dan Pembahasan}

Entri data merupakan hal pertama yang dilakukan saat akan membuat penjadwalan dalam aplikasi program. Kemudian menentukan hubungan antar kegiatan agar jadwal tersusun dengan baik dan saling berkesinambungan. Dalam entri data sebuah aplikasi program akan berbeda caranya. Begitu pula hubungan antar kegiatannya. Pada Microsoft Project, Project Libre dan Gantt Project tidak terdapat perbedaan yang siknifikan.

Penentuan Jam kerja sangat berpengaruh pada penyelesaian suatu proyek, semakin banyak hari kerja dalam satu minggu, maka semakin cepat selesai proyek tersebut. Microsoft Project, Project Libre dan Gantt Project tidak memiliki perbedaan yang siknifikan, namum dalam hal ini Gantt Project memiliki keunggulan dibanding dua aplikasi program lain nya karna mampu menyesuaikan hari libur berdasarkan Negara.

Sumber daya juga merupakan sebuah item penting sebuah proyek. Dalam aplikasi program manajemen proyek fitur sumber daya merupakan hal yang wajib dimiliki. Sumber daya terdiri dari beberapa jenis diantaranya adalah sumber daya manusia, sumber daya alat, dan sumber daya material. Pada Microsoft Project, Project Libre dan Gantt Project tidak terdapat perbedaan yang siknifikan.

Baseline adalah suatu rencana baik jadwal maupun biaya yang telah disetujui dan tetapkan. Baseline digunakan sebagai patokan dan perbandingan antara rencana kerja yang ada dengan kenyataan dilapangan. Baseline digunakan sebagai alat pemandu sekaligus control akan pembangunan proyek baik dari segi ketetapan waktu maupun biaya proyek. Ketidaksesuaian Baseline (Perencanaan) dengan perkembangan proyek secara real dapat dipantau sejak dini dan anda dapat melakukan 
penyesuaian dengan membuat perubahan rencana proyek. Pada Microsoft Project 2007 dan Project Libre terdapat menu unuk menggunakana Baseline dan hanya terdapat perbedaan penampilan Baseline pada masing-masing aplikas program, namun menu ini tidak dimiliki oleh Gantt Project.

Tracking adalah mengaktualisasikan kenyataan di lapangan ke rencana kerja sehingga akan dapat dianalisa apakah biaya yang dikeluarkan sesuai dengan volume kerja yang telah dilaksanakan. Pada Microsoft Project 2007 dan Project Libre terdapat menu unuk menggunakana Tracking namun menu ini tidak dimiliki oleh Gantt Project.

Report atau laporan merupakan hal yang paling penting di seluruh aktifitas, dan pada bagian ini akan dibahas laporan apa saja yang dapat ditampilkan setelah mengaktualisasikan pelaksanaan proyek pada aplikasi program. Report pada Microsoft Project 2007 (Overview, Current Activities, Cost Report, Assignment Report, Workload Report, Custom), Report pada Project Libre (Project Details Report, Resources Information, Task Information, Who Does What), Pada Gantt Project tidak terdapat menu Report seperti pada dua aplikasi program lainnya. Dan hardcopy yang didapat dari Gantt Project hanya berupa penjadwalan dan resources saja.

Pada penelitian tugas akhir ini penulis akan menganalisis peran penggunakan aplikasi program untuk penjadwalan pada proyek konstruksi menggunakan data yang telah didapatkan dari studi kasus Supervisi Penataan Pelabuhan Dumai. Dalam menilai aplikasi program digunakan 12 kriteria evaluasi yang diambil dari penelitian Octavia dan Tandoyo (2013)

Tabel 1. Tabel perbandingan tiga aplikasi program menggunakan 12 kategori.

\begin{tabular}{|c|c|c|c|c|}
\hline No & Kategori & Ms. Project & Project Libre & Gantt Project \\
\hline 1 & $\begin{array}{l}\text { Persyaratan } \\
\text { Untuk } \\
\text { Hardware dan } \\
\text { aplikasi } \\
\text { program Serta } \\
\text { Batasannya }\end{array}$ & $\begin{array}{l}\text { Persyaratan } \\
\text { hardware yang } \\
\text { dibutuhkan } \\
\text { cukup besar. } \\
\text { Batasan sistem } \\
\text { operasi } \\
\text { Windows XP }\end{array}$ & $\begin{array}{l}\text { Persyaratan } \\
\text { hardware yang } \\
\text { dibutuhkan } \\
\text { sedang. } \\
\text { Batasan sistem } \\
\text { operasi } 32 \text { bit. }\end{array}$ & $\begin{array}{l}\text { Persyaratan } \\
\text { hardware yang } \\
\text { dibutuhkan } \\
\text { kecil. } \\
\text { Sistem operasi } \\
\text { Minimal } \\
\text { Windows XP, } \\
\text { Linux and } \\
\text { MacOSX. }\end{array}$ \\
\hline 2 & $\begin{array}{l}\text { Memiliki } \\
\text { Fitur } \\
\text { Pendukung } \\
\text { Skema } \\
\text { Jaringan } \\
\text { Proyek }\end{array}$ & $\begin{array}{l}\text { Penjadwalan } \\
\text { tersusun secara } \\
\text { otomatis. } \\
\text { Memiliki } \\
\text { banyak skema } \\
\text { jaringan serta } \\
\text { tampilan yang } \\
\text { lebih jelas. }\end{array}$ & $\begin{array}{l}\text { Fitur skema } \\
\text { jaringan pada } \\
\text { Project Libre } \\
\text { memiliki } \\
\text { kemampuan } \\
\text { yang hampir } \\
\text { sama dengan } \\
\text { Microsoft Project } \\
2007 \text {. }\end{array}$ & $\begin{array}{l}\text { Memiliki } \\
\text { keterbatasan } \\
\text { varian skema } \\
\text { jaringan dan } \\
\text { tidak selengkap } \\
\text { fitur dari } \\
\text { Microsoft } \\
\text { Project } 2007 \\
\text { dan Project } \\
\text { Libre. }\end{array}$ \\
\hline
\end{tabular}




\begin{tabular}{|c|c|c|c|c|}
\hline No & Kategori & Ms. Project & Project Libre & Gantt Project \\
\hline 3 & $\begin{array}{l}\text { Kapasitas } \\
\text { aplikasi } \\
\text { program } \\
\text { dalam } \\
\text { Mengatur } \\
\text { Kegiatan } \\
\text { Proyek }\end{array}$ & $\begin{array}{l}\text { Penjadwalan } \\
\text { tersusun secara } \\
\text { otomatis } \\
\text { setelah } \\
\text { penginputan } \\
\text { nomor aktivitas } \\
\text { Predecessors. }\end{array}$ & $\begin{array}{l}\text { Project Libre } \\
\text { memiliki } \\
\text { kemampuan } \\
\text { yang sama } \\
\text { dengan Microsoft } \\
\text { Project 2007. }\end{array}$ & $\begin{array}{l}\text { Gantt Project } \\
\text { juga memiliki } \\
\text { kemampuan } \\
\text { yang sama } \\
\text { dengan } \\
\text { Microsoft } \\
\text { Project } 2007 .\end{array}$ \\
\hline 4 & $\begin{array}{l}\text { Proses Entri } \\
\text { Data, } \\
\text { Verifikasi } \\
\text { Data, dan } \\
\text { Perubahan } \\
\text { Data }\end{array}$ & $\begin{array}{l}\text { Dilakukan } \\
\text { secara manual } \\
\text { atau copy data } \\
\text { dari Ms. Excel. } \\
\text { Perubahan } \\
\text { data bisa } \\
\text { dilakukan } \\
\text { manual } \\
\text { maupun } \\
\text { otomatis. }\end{array}$ & $\begin{array}{l}\text { Project Libre } \\
\text { memiliki } \\
\text { kemampuan } \\
\text { yang sama } \\
\text { dengan Microsoft } \\
\text { Project } 2007 .\end{array}$ & $\begin{array}{l}\text { Gantt Project } \\
\text { juga memiliki } \\
\text { kemampuan } \\
\text { yang sama } \\
\text { dengan } \\
\text { Microsoft } \\
\text { Project } 2007 . \\
\text { Namun tidak } \\
\text { dapat copy data } \\
\text { dari Ms. Excel. }\end{array}$ \\
\hline 5 & $\begin{array}{l}\text { Perhitungan } \\
\text { Waktu yang } \\
\text { Tepat untuk } \\
\text { Aktivitas } \\
\text { Proyek }\end{array}$ & $\begin{array}{l}\text { Microsoft } \\
\text { project } \\
\text { memiliki fitur } \\
\text { pengaturan } \\
\text { waktu yang } \\
\text { flexible } \\
\text { sehingga } \\
\text { meningkatkan } \\
\text { ketepatan } \\
\text { dalam } \\
\text { pengaturan } \\
\text { waktu. }\end{array}$ & $\begin{array}{l}\text { Project Libre } \\
\text { memiliki } \\
\text { kemampuan } \\
\text { yang sama } \\
\text { dengan Microsoft } \\
\text { Project } 2007 .\end{array}$ & $\begin{array}{l}\text { Project Libre } \\
\text { memiliki } \\
\text { kemampuan } \\
\text { yang sama } \\
\text { dengan } \\
\text { Microsoft } \\
\text { Project } 2007 .\end{array}$ \\
\hline 6 & $\begin{array}{l}\text { Laporan } \\
\text { Kemajuan } \\
\text { Proyek }\end{array}$ & $\begin{array}{l}\text { Microsoft } \\
\text { Project dapat } \\
\text { menampilkan } \\
\text { kemajuan } \\
\text { aktivitas pada } \\
\text { gant chart dan } \\
\text { network } \\
\text { diagram. }\end{array}$ & $\begin{array}{lr}\text { Project } & \text { Libre } \\
\text { dapat } & \\
\text { menampilkan } & \\
\text { kemajuan } & \\
\text { aktivitas } & \text { pada } \\
\text { gant } & \text { chart } \\
\text { namun } & \text { tidak } \\
\text { pada } & \text { network } \\
\text { diagram. } & \end{array}$ & $\begin{array}{l}\text { Gantt Project } \\
\text { dapat } \\
\text { menampilkan } \\
\text { kemajuan } \\
\text { aktivitas pada } \\
\text { Gantt Chart. }\end{array}$ \\
\hline 7 & $\begin{array}{l}\text { Kontrol dan } \\
\text { Pemantauan } \\
\text { terhadap } \\
\text { Biaya }\end{array}$ & $\begin{array}{l}\text { Microsoft } \\
\text { Project mampu } \\
\text { menghitung } \\
\text { biaya proyek, } \\
\text { budget untuk } \\
\text { tiap proyek, } \\
\text { mengakumulas } \\
\text { i biaya secara }\end{array}$ & $\begin{array}{lr}\text { Sama } & \text { halnya } \\
\text { dengan } & \text { Microsoft } \\
\text { Project, Project } \\
\text { Libre } \\
\text { mampu juga } \\
\text { menghitung } \\
\text { biaya proyek, } \\
\text { budget untuk }\end{array}$ & $\begin{array}{l}\text { Gantt Project } \\
\text { merupakan } \\
\text { aplikasi } \\
\text { program yang } \\
\text { berfocus } \\
\text { kepada } \\
\text { penjadwalan. } \\
\text { Sehingga tidak }\end{array}$ \\
\hline
\end{tabular}




\begin{tabular}{|c|c|c|c|c|}
\hline No & Kategori & Ms. Project & Project Libre & Gantt Project \\
\hline & & $\begin{array}{l}\text { otomatis dan } \\
\text { menampilkan } \\
\text { variasi } \\
\text { perubahan } \\
\text { biaya yang } \\
\text { terjadi apabila } \\
\text { terjadi } \\
\text { perubahan } \\
\text { jadwal. }\end{array}$ & $\begin{array}{l}\text { tiap proyek, } \\
\text { mengakumulasi } \\
\text { biaya secara } \\
\text { otomatis, dan } \\
\text { menampilkan } \\
\text { variasi } \\
\text { perubahan biaya } \\
\text { yang terjadi }\end{array}$ & $\begin{array}{l}\text { terdapat fitur } \\
\text { perhitungan } \\
\text { biaya dalam } \\
\text { aplikasi } \\
\text { program ini. }\end{array}$ \\
\hline 8 & $\begin{array}{l}\text { Perencanaan } \\
\text { Sumber Daya } \\
\text { (Resources } \\
\text { Planning) }\end{array}$ & $\begin{array}{l}\text { Menyediakan } \\
\text { fitur pengisian } \\
\text { sumber daya } \\
\text { berupa pekerja, } \\
\text { material dan } \\
\text { biaya. }\end{array}$ & $\begin{array}{l}\text { Menyediakan } \\
\text { fitur pengisian } \\
\text { sumber daya } \\
\text { berupa pekerja, } \\
\text { dan material. }\end{array}$ & $\begin{array}{l}\text { Gantt Project } \\
\text { memiliki } \\
\text { beberapa jenis } \\
\text { peran pekerja } \\
\text { yang dapat } \\
\text { didefinisikan } \\
\text { secara lebih } \\
\text { terperinci. }\end{array}$ \\
\hline 9 & $\begin{array}{l}\text { Laporan Hasil } \\
\text { Pengujian }\end{array}$ & $\begin{array}{l}\text { Microsoft } \\
\text { Project } \\
\text { memiliki } \\
\text { beberapa fitur } \\
\text { dalam } \\
\text { menampilkan } \\
\text { laporan hasil } \\
\text { pengujian, } \\
\text { diantaranya } \\
\text { Overview, } \\
\text { Current } \\
\text { Activity, Costs, } \\
\text { Assigments, } \\
\text { dan Workload. }\end{array}$ & $\begin{array}{lr}\text { Project } & \text { Libre } \\
\text { memiliki } & \text { fitur } \\
\text { yang } & \text { mirip } \\
\text { dengan } & \text { Microsoft } \\
\text { Project namun } & \text { namilan } \\
\text { dengan tampilan } & \text { yang berbeda. } \\
\text { Fitur laporan } \\
\text { hasil pengujian } \\
\text { yang dimiliki } \\
\text { Project } \quad \text { Libre } \\
\text { diantaranya } \\
\text { Project Details, } \\
\text { Resources } \\
\text { Information, } \\
\text { Task } \\
\text { Information, } \\
\text { Who Does } \text { What. }\end{array}$ & $\begin{array}{lr}\text { Gantt } & \text { Project } \\
\text { tidak } & \text { terdapat } \\
\text { menu } & \text { Report } \\
\text { seperti } & \text { pada } \\
\text { dua aplikasi } & \text { program } \\
\text { lainnya. Dan } & \text { hardcopy yang } \\
\text { didapat dari } & \text { Gantt Project } \\
\text { hanya berupa } \\
\text { penjadwalan } \\
\text { dan resources } \\
\text { saja. }\end{array}$ \\
\hline $\begin{array}{l}1 \\
0\end{array}$ & $\begin{array}{l}\text { Pilihan } \\
\text { Berbagai } \\
\text { Macam } \\
\text { Tampilan } \\
\text { Pada aplikasi } \\
\text { program } \\
\text { (Software } \\
\text { Interface } \\
\text { Option) }\end{array}$ & $\begin{array}{l}\text { Dapat } \\
\text { menyimpan } \\
\text { data dengan } \\
\text { format .xml } \\
\text { sehingga data } \\
\text { filenya dapat } \\
\text { disimpan } \\
\text { terpisah, dapat } \\
\text { dicopy, cut, dan } \\
\text { paste dengan } \\
\text { mudah } \\
\text { kedalam }\end{array}$ & $\begin{array}{l}\text { Project Libre } \\
\text { dapat } \\
\text { menyimpan data } \\
\text { dengan format } \\
\text { xml dan .pod. } \\
\text { dan tidak } \\
\text { memiiki } \\
\text { kemampuan } \\
\text { berintegrasi } \\
\text { dengan Mircosoft } \\
\text { Excel Workbook. }\end{array}$ & $\begin{array}{lr}\text { Sama } & \text { halnya } \\
\text { dengan } & \text { Project } \\
\text { Libre, } & \text { Gantt } \\
\text { Project hanya } \\
\text { dapat } \\
\text { menyimpan } \\
\text { data dengan } \\
\text { format .xml } \\
\text { dan gan dan } \\
\text { tidak memiliki } \\
\text { kemampuan } \\
\text { berintegrasi }\end{array}$ \\
\hline
\end{tabular}




\begin{tabular}{|c|c|c|c|c|}
\hline No & Kategori & Ms. Project & Project Libre & Gantt Project \\
\hline & & $\begin{array}{l}\text { flashdisk, } \\
\text { hardisk } \\
\text { external, atau } \\
\text { Compact Disc } \\
\text { dan dapat } \\
\text { berintegrasi } \\
\text { dengan } \\
\text { Mircosoft Excel } \\
\text { Workbook. }\end{array}$ & & $\begin{array}{l}\text { dengan } \\
\text { Mircosoft Excel } \\
\text { Workbook. }\end{array}$ \\
\hline $\begin{array}{l}1 \\
1\end{array}$ & $\begin{array}{l}\text { Kenyamanan } \\
\text { Tampilan bagi } \\
\text { Pengguna dan } \\
\text { Pendokument } \\
\text { asian aplikasi } \\
\text { program }\end{array}$ & $\begin{array}{l}\text { Memiliki } \\
\text { kenyamanan } \\
\text { tampilan yang } \\
\text { sangat baik. }\end{array}$ & $\begin{array}{l}\text { Tampilan Project } \\
\text { Libre } \\
\text { Mirip dengan } \\
\text { Microsoft Project } \\
\text { namun tidak } \\
\text { senyaman } \\
\text { tampilan } \\
\text { Microsoft } \\
\text { Project. }\end{array}$ & $\begin{array}{l}\text { Memiliki } \\
\text { tampilan yang } \\
\text { tidak user- } \\
\text { friendly. }\end{array}$ \\
\hline $\begin{array}{l}1 \\
2\end{array}$ & $\begin{array}{l}\text { Kebutuhan } \\
\text { untuk } \\
\text { Manajemen } \\
\text { Proyek dan } \\
\text { Persyaratan } \\
\text { Kesesuaian } \\
\text { Data yang } \\
\text { akan } \\
\text { Dimasukkan }\end{array}$ & $\begin{array}{l}\text { Pengguna } \\
\text { mudah untuk } \\
\text { mempelajari } \\
\text { dan } \\
\text { mengoperasika } \\
\text { nnya. Namum } \\
\text { memiliki harga } \\
\text { lisence yang } \\
\text { mahal. }\end{array}$ & $\begin{array}{l}\text { Pengguna } \\
\text { mudah untuk } \\
\text { mempelajari dan } \\
\text { mengoperasikan } \\
\text { nya. Dan gratis } \\
\text { digunakan siapa } \\
\text { saja. }\end{array}$ & $\begin{array}{l}\text { Pengguna } \\
\text { harus memiliki } \\
\text { ketelitian } \\
\text { dalam } \\
\text { mengoperasika } \\
\text { nnya. Dan } \\
\text { gratis } \\
\text { digunakan } \\
\text { siapa saja. }\end{array}$ \\
\hline
\end{tabular}

\section{Simpulan}

Dari 12 kategori Analisa Perbandingan yang digunakan Microsoft Project memiliki kelengkapan menu dan sangat user-friendly namun berbayar. Sedangkan Project Libre hampir mirip menu nya seperti Microsoft Project, tetapi Project Libre merupakan aplikasi program yang tidak berbayar. Namun pada Gantt Project banyak sekali kekuranganya dibandingkan dengan dua aplikasi program lainnya. Namun gantt project memiliki kelebihan selain merupakan aplikasi program gratis Gantt Project menbutuhkan sedikit ruang. 


\section{Daftar Pustakaan}

Mockler, R.J. 1972. The Management Control Process. New Jersey: Prentice Hall.

Octavia, I.K. dan Tandoyo, E.C. 2013. Perbandingan aplikasi program Microsoft Project dan Primavera dalam Penjadwalan Proyek Konstruksi, 2-8

Widiasanti, I dan Lenggogeni. 2013. Manajemen Konstruksi. Bandung: PT. Remaja Rosdakarya 